\title{
Being a nurse after having been a nursing student-worker: an approach of social phenomenology*
}

\author{
Ser enfermeiro tendo sido estudante-trabalhador de enfermagem: um enfoque da fenomenologia social
}

Ser enfermero habiendo sido estudiante-trabajador de enfermería: un enfoque de la fenomenología social

\author{
Maria Lucia Alves de Sousa Costa ${ }^{1}$, Miriam Aparecida Barbosa Merighi², Maria \\ Cristina Pinto de Jesus ${ }^{3}$
}

\begin{abstract}
Objective: To understand the transition from being a nurse after having been a nursing student-worker in the face-to-face relationship with other nurses from conventional graduation. Methods: This is a study using qualitative approach founded on the Phenomenological Sociology proposed by Alfred Schutz. Fifteen interviews were carried out, of which eight were performed with nursing studentworkers, and seven with nurses who underwent conventional graduation and held supervision or leader positions in nursing units. The reports were analyzed according to this theoretical-methodological framework. Results: Being a nurse after having been a nursing student-worker in a world with other nurses means experiencing a transformation in not only one's everyday routines, but also one's inner being, behavior, and social relationship. Conclusions: There is a need for educational organizations and hospital institutions to invest in continuous education with a view to look carefully at nursing student-workers who are studying to become a nurse.
\end{abstract}

Keywords: Nursing education; Workers; Students, Nursing; nurses; Nurses, male; Philosophy, nursing; Qualitative research

\section{RESUMO}

Objetivo: Compreender a transição de ser enfermeiro tendo sido estudante-trabalhador de enfermagem na relação face a face com outros enfermeiros de formação convencional. Métodos: Estudo de abordagem qualitativa fundamentada na Sociologia Fenomenológica de Alfred Schutz. Foram realizadas 15 entrevistas, sendo oito com enfermeiros que foram estudantes-trabalhadores de enfermagem e sete com enfermeiros de formação convencional que exerciam supervisão ou chefia de unidades de enfermagem. Os discursos foram analisados segundo esse referencial teórico-metodológico. Resultados: Ser enfermeiro tendo sido antes estudante-trabalhador de enfermagem em um mundo com outros enfermeiros significa vivenciar uma transformação não somente no seu fazer cotidiano, mas também transformar seu próprio meio interno, seu comportamento e relacionamento social. Conclusões: Há necessidade de investimento por parte dos órgãos formadores e da educação continuada das organizações hospitalares no sentido de um olhar atentivo para o estudante-trabalhador de enfermagem que está se formando enfermeiro.

Descritores: Educação em enfermagem; Trabalhadores; Estudantes de enfermagem; Enfermeiras; Enfermeiros; Filosofia em enfermagem; Pesquisa qualitativa

\section{RESUMEN}

Objetivo: Comprender la transición de ser enfermero habiendo sido estudiante-trabajador de enfermería en la relación frente a frente con otros enfermeros de formación convencional. Métodos: Se trata de un estudio con abordaje cualitativo fundamentado en la Sociología Fenomenológica de Alfred Schutz. Se llevó a cabo 15 entrevistas, de las cuales ocho con enfermeros que fueron estudiantes-trabajadores de enfermería y siete con enfermeros de formación convencional que ejercían supervisión o jefatura de unidades de enfermería. Los discursos fueron analizados según ese referencial teórico-metodológico. Resultados: Ser enfermero habiendo sido antes estudiante-trabajador de enfermería en un mundo con otros enfermeros significa vivenciar una transformación no sólo en su quehacer cotidiano, sino también en su propio medio interno, su comportamiento y relación social. Conclusións: Hay necesidad de inversión por parte de los órganos formadores y de la educación continuada de las organizaciones hospitalarias en el sentido de una mirada atenta al estudiante-trabajador de enfermería que se está formando como enfermero.

Descriptores: Educación en enfermería; Trabajadores; Estudiantes de enfermería; Enfermeras; Enfermeros; Filosofía en enfermería; Investigación cualitativa

\footnotetext{
${ }^{*}$ This study was extracted from the Doctorate dissertation presentd to the Escola de Enfermagem da Universidade de São Paulo - USP - São Paulo (SP), Brazil.

${ }^{1}$ PhD, Professor of the Escola de Enfermagem da Santa Casa de Misericórdia - São Paulo (SP), Brazil.

${ }^{2}$ Free-lecturer Professor of the Escola de Enfermagem da Universidade de São Paulo - USP - São Paulo (SP), Brazil.

${ }^{3}$ PhD, Professor of the Universidade Federal de Juiz de Fora (MG), Brazil.
} 


\section{INTRODUCTION}

Over the last years, the phenomenon "nursing student-worker" has increased in nursing undergraduate courses. The search appears to be increasing, specifically because it lures the studentworker, who, highly motivated, will overcome great challenges to become a nurse.

Costa's master's thesis, which used a qualitative method, described the perception that nursing student-workers had of their socioeconomic and cultural conditions, their adversities and expectations, and the understanding regarding their returning to school after breaking the academic sequence, in search for a university degree, the reason for this pursuit despite the adversities, and their expectations towards the nursing diploma ${ }^{(1)}$.

The subjects in that study reported a "nearly unbearable existence" since they had to balance work and school, without being able to properly dedicate themselves to these activities, having no time for leisure and family, experiencing financial troubles, since most of their budget was for paying tuition. However, despite this situation, they did not give up ${ }^{(1)}$.

Costa's doctorate dissertation, pointed out the characteristics of the students of the studied institution, and emphasized that their age group was above that usually observed in public universities, with many even older than their professors. In addition to working, some of these students already had a family to support ${ }^{(2)}$.

The author emphasized that the professors of the studied institution considered this type of student "wearisome", since some came to class quite tired after working night shifts and others left early for their afternoon shifts. Furthermore, many had low scores in theoretical classes, which was allegedly due to the lack of time and disposition to study. In practical classes and activities, however, they excelled in the motor skills and practical knowledge gathered over the years working at hospitals. The half-day undergraduate course offered students the chance of keeping one or more jobs in the afternoon or night, and, at the same time, study. The aspiration to obtain a university degree in nursing is a priority to these students. This diploma is their opportunity to ascend both professional and socially.

On the other hand, our practice shows that many nurses make serious restrictions when speaking about their colleagues, who, over their professional pathway, have been nursing auxiliaries or technicians. This subject arises much discussion, as the number of professional with theses particularities increases in the work market.
Nurses with a conventional professional education and those who were nursing student-workers have to deal with a new situation in this imposed relationship. They start sharing the same time and space, not simply as professionals with a university and technical level degree, but, now, as people with the same professional level, in a face-to-face relationship. The role that each one has, in this new relationship, has now to be redefined.

Taking these aspects into consideration, the purpose of the present study was to understand the transition to becoming a nurse after having been a nursing student-worker in the face-to-face relationship with other nurses with conventional education. We believe that this type of professional is, currently, a reality in the work-market, and their presence should be valued with a view to promote their full development and overcoming this verified situation.

\section{Theoretical-methodological framework}

Through this study, we attempted to apprehend the reasons that characterize human actions, but not in the individual context of action, since we believe that becoming a nurse is not an individual action. Despite this action being experienced by the former students who begin their professional career, this action takes place in a world shared with others, and, therefore, has an intersubjective meaning, contextualized in the social world.

Therefore, to cover this subject from the view of the person experiencing the situation, we chose to perform the research using a qualitative approach and a phenomenological focus, since phenomenology has the purpose to understand the individual through a reality they intentionally experience with their life world, in an involving and shared fashion.

Searching for the opportunity to understand the phenomenon "nurse who has been a nursing studentworker in a world with other nurses", we found a possibility in the Social Phenomenology proposed by Alfred Schutz. Through this framework, we would be able to understand these nurses' day-to-day experiences as elements that act, interact, and belong to the world of life.

Schutz studied the subjective impulses of human action, and found the motivation theory, which reveals the double character of existential motivation: men act as a function of the motivations directed to objectives for the future, named "motives with a view to" or "motives to". On the other hand, men have reasons for their actions and worry about them. These reasons have their roots in previous experiences, in the personality that an individual developed through 
life. Schutz named theses reasons "motives why". Furthermore, Schutz insisted that the subjective meanings behind the motivation should be clearly differentiated from the objective meanings ${ }^{(3)}$.

Throughout the experience of performing an action, according to the preconceived plan, the actor directly experiences the "motives with a view to". Therefore, they are essentially subjective. On the contrary, during the action, the actor is not aware of the "motives why", which are only understood retrospectively, during a moment of reflection, which can occur, but not necessarily does, after completing the act. On the other hand, even an observer could reconstruct the "motives why" of an act, based on what was accomplished ${ }^{(4)}$.

For Social Phenomenology, there is no sense in studying each actor's particular behavior, because the focus of interest should be a typical characteristic of a social group living a certain typical situation ${ }^{(5)}$.

Typology is a analytical-descriptive structure, unmistakable with the explicative theory, with a restricted use; it is a research instrument and not an explanation method that serves to order the phenomena, to indicate their forms of articulation, and to see how the meanings articulate ${ }^{(6)}$.

The theoretical concepts of Social Phenomenology outlined herein were used as the basis for understanding how the intersubjective experience occurs for nurses with conventional education and nurses who were nursing student-workers. This basis was also used to unveil what might be hidden in the transition of becoming a nurse after having been a nursing student-worker.

Based on the Social Phenomenology proposed by Alfred Schutz, we sought to establish the "lived type" conventional-education nurse, the "lived type" nurse who had been a nursing student-worker, as well as the type of face-to-face relationship that exists between these two lived types. We, thus, obtained the "motives to" and the "motives why" of these two types of nurses regarding the situation of being a nurse after having been a nursing student-worker.

\section{METHODS}

This study included nurses with conventional education who held supervision or leadership positions in nursing units, having under their supervision nurses who had been nursing student-workers, not necessarily the subjects who were interviewed, and nurses who for some moment in their life, or during their undergraduate course, had a job as nursing auxiliary or technician.

Due to the study methodology, we did not establish the number of nurses to be interviewed. The interviews were considered completed when we realized the convergence or "motives to" and "motives why" in the subjects" reports. We performed 15 interviews, of which eight interviewees were nurses who had been nursing student-workers, and seven conventional-education nurses with supervision or leadership job positions in a nursing unit.

The project was approved by the University of São Paulo College of Nursing Research Ethics Committee, and the participants provided written consent. The subjects' anonymity was ensures, in agreement with the National Health council Resolution 196/96 regarding ethics in research involving human beings $^{(7)}$.

The chosen studied location were two hospitals (one public and one private) in the city of São Paulo, which had both types of nurses sharing the same time and space, with face-to-face relationships.

The data were collected in May and June 2000, by means of individual interviews, according to the phenomenological approach. We approached the subjects' reports without precious interpretations, scripts, or guiding questions, trying to adopt, throughout the interview, a posture that would allow us to "relive, assign themes, and eidetically understand the daily life phenomena, according to how they are experienced and consciously perceived"(8).

The research used the following guiding questions for nurses with conventional education: how do you see nurses that used to be nursing student-workers? For nurses who had been nursing student-workers, the question was: how has it been, for you, to be a nurse after having been a nursing student-worker?

At the beginning of the interviews, we explained the study objectives and offered to clarify any doubts. We also asked the participants' for authorization to record the interview, and all agreed.

\section{RESULTS}

The participants' reports were analyzed according to the recommendations of social phenomenology researchers ${ }^{(5,9-10)}$. We carefully and patiently grouped and regrouped the subjects' reports according to their similarity, and obtained concrete categories of their experience. These categories translate the points of view of nurses who had been nursing studentsworkers and nurses with conventional education, in the face-to-face relationship they experienced.

Thus, from the concrete categories of the experience emerges the typology of the nurse who had been a nursing student-worker and that of the nurse with conventional education, comprised by the 
"motives to" and "motives why" for each type of face-to-face relationship that they experienced.

The methodological framework allowed for describing two experienced types of nurses that share a face-to-face social relationship marked by important paradoxes.

\section{Comprehensive analysis of the type experienced} nurses who had been nursing students-workers

Answering the guiding question, the nurses who had been nursing student-workers led to our understanding of the action: "being a nurse after having been a nursing student-worker in a world with other nurses" who graduated in a conventional fashion.

In their reports, we searched for the "motives to", that is, the projects that encouraged them to becoming nurses. We obtained the following categories: Transforming oneself; Institutional challenges; Readapting oneself; and Recognizing.

In the category transforming oneself, the subjects reported that they wished to transform into nurses, but they needed to leave a situation that they had control over to take on another that was new to them. Therefore, they realized the great difficulty; the herculean task they had to face. Below, we highlight an excerpt from one of the reports: "In the beginning, I was really lost because I thought I had to stand by the patient, stand by the auxiliary, help moving, help controlling, and that is not a nurse's view; well, it can be, but it depends on the situation, but, in my case, that's how I would see it, but not the institution, that wasn't the case ..."

The group of nursing auxiliaries/technicians is closely in touch with the group of nurses; they share the daily situation of holding a lower position in the nursing hierarchy. However, when they seek to enter a new group, they report not knowing what it is to act like a nurse, what the nurse's role is, or what the nurse's view is, as if they were unable to decode a subliminal message, a code referring to an expected conduct. Apparently, neither the daily living with nurses nor completing the nursing undergraduate course were enough to help them decipher the message.

The members of the social group nursing auxiliaries/ technicians have a conduct system define by the group. This system, according to Schutz ${ }^{(1)}$, originated in previous situations, created an interpretation code that, until that moment, was efficient, and thus incorporated by the group. For this code, the world will remain the same as it has always been, and anything done again, in the same way, will have a similar result. The group tends to always use this code, since it has become efficient, but, now, when they search to become a nurse, the previous code is no longer useful, rather it is inefficient among the new group; this group did not receive, with their nursing diploma, the decoder for the new code.
The nurses that had been nursing students-workers predicted they would have to deal with institutional challenges to become nurses. They reported having to leave their shift, sector, or institution where they worked as nursing auxiliaries/technicians to arrive or return with new competencies. This appears in one of the subjects' reports: "before starting a job as a nurse, I first had to quit at the hospital, so I could start with a new face, I don't know if this is prejudice or what, but I had to quit ..."

In the search for being accepted by the nursing team, the nurses who had been nursing student-workers tried to readapt themselves to be acknowledged by the new group; once they used to be in a lower hierarchic position, but, now, share the same level.

Previously, nurses who seek to enter the new group could be considered a medium-level worker, an uninterested observer of the relationship that took place between nurses. They could observe but not take part in this context, since their competence was different from that of nurses. The idea of cultural standard of the new group exists for the stranger as a function of the interpretation of its original group; however, the stranger who enters a new group is close to changing from an uninterested observer into a new group member. The cultural standard of the new group is no longer a subject of his/her thought, but a segment of the world that has to be named through actions ${ }^{(10)}$.

Considering Schutz's concepts about the code for interpreting previous experiences with a view to make new decisions, we believe that nurses who were once nursing auxiliaries/technicians now will have to perform actions with the purpose to integrate in the group of nurses. Therefore, they try to re-elaborate the relationship that they kept with this group, but they do it by means of their coordinate system used as a reference code in their lives as nursing auxiliaries/technicians. They also assume a submissive behavior, which was learned when working as a auxiliary/technician. The following excerpt illustrates these statements: "maybe because I used to be an auxiliary and all, I try to stay a few steps bebind ..."

The reports reveal that these subjects ask the nursing supervisor for help to mediate the difficult relationship they maintain with their nursing colleagues: “... regarding the nurses, I had some problems because some colleagues did not accept me and that's just how it was, I would come and they would not respect me as a professional, we had true arguments, it was very embarrassing, I was always fighting ... it was difficult to work together".

In the search for their being recognized as a nurse, the nursing student-workers predicted they would also have to readapt their relationships with the nursing auxiliaries and technicians. They belonged to that same hierarchic level, to the same social group, but now the new nurses need to perform actions with a view to 
differentiate them from their original group and give them the status of "leaders", characteristic of the new role they have assumed.

These subjects report they feel insecure with the fact they have to work with former colleagues and because of the difficulties in the new relationships. They realize there is a need to change and that nursing auxiliaries and technicians, who now offer resistance in accepting them as nurses and leaders, do not accept this change.

They find their former colleagues' behavior is awkward, and hope to find support in the people and environment they have always known, and think they still know. This environment and these people belong to the reference code of the former nursing auxiliary/ technician, typified as friends. They assumed they could simply consider it true and act as they had always done toward them. However, what they do not understand is that what happens when these people who also behaved one expected way (typified) start acting differently. The following report illustrates the surprise of the nurse who had been a nursing student-worker: " ... I used to think: where am I? What country is this? Because, all of a sudden, instead of being welcomed by my own colleagues, they though it wasn't good because now I would be giving them orders ..."

In this sense, Schutz states that those who left their original group enter a new social dimension, which does not include the coordinate system used as a reference in the lives of those who stayed. Since they share the same time and space, there is a reduced field in which the other's expressions are presented and subject to interpretation $^{(11)}$.

This fact is similar to what happens with the nurses that were once nursing auxiliaries/technicians, because, besides changing social groups, these subjects were moved away from the colleagues of the shift, sector, or institution they used to work in. Therefore, as a result, the face-to-face relationship was broken and the continuity of the common history that was being constructed was interrupted, and is no longer shared in the same biographic situation.

After examining and understanding the "motives for" of the actions that encouraged these subjects to become nurses, it is now necessary to search in the "motives why" the reasons that moved these people in the direction of this project. These reasons are within the genesis of the project and are found in the previous experiences.

The value acquired for having completed a university course and the confidence in performing the procedures comprised the context of the meanings that composed the "motives why". It is observed that the experience and the skillful nursing care practice can provide the confidence needed to face the challenges of transformation. These subjects also reported the fact that their knowing the work place makes this process easier, and that the fact that they already belonged to the nursing team adds confidence regarding the profession, even before practicing it.

The lived type "nurse who had been a nursing studentworker" can be described as one who moves from a situation they have under control to a new, unknown situation; faces institutional challenges; has to readapt their relationships with nursing auxiliaries/technicians and nurses to stop being an auxiliary/technician and become a nurse. The fact of having attended university makes them feel appreciated. Having been a nursing auxiliary/ technician gave them the confidence to achieve this transformation due to the accumulated technicalscientific knowledge and experience.

\section{Comprehensive analysis of the "lived type" nurses with conventional education in their relationship with nurses that had been nursing students-workers}

As seen above, the nurses who had been nursing students-workers need to act to be recognized as nurses, not only by the nursing auxiliaries and technicians, but also by their fellow nurses with conventional education.

This need is perceived by the nurses with conventional education and appears in their reports that comprise the categories Leadership and Professional development, thus constituting the "motives to" for conventionaleducation nurses in the relationship with nurses who had been nursing student-workers.

Taking on the leader role in the nursing team and speaking up in the health team are considered relevant factors for the nurse who had been a nursing studentworker to be able to be set apart from the nursing auxiliary/technician, and enter the nurses' social group and be recognized as an equal. However, conventionaleducation nurses recognized that, for them to reach a leader position, they would have to overcome the fact that they had been nursing auxiliaries/technicians, as observed in the following report: " ... commanding becomes difficult, not because she, maybe, like, she was an auxiliary and now she's giving orders, and there's this difficulty, I don't know, but we hope this will be solved soon ..."

Also in this category, besides indicating the need to overcome this "difficulty" to become a leader, the conventional-education nurses refer that nurses who were once nursing auxiliaries/technicians are "insecure", "afraid to talk", and "do not know the game of management".

Therefore, making the desired and expected change is not an easy task; rather it is a complex process in which both lived types of nurses should agree about what behavior is expected from those who changed from being nursing auxiliaries/technicians to becoming nurses. 
In this process of transformation, it should be considered that the two lived types of nurses originated from different social groups have their own valid relevance systems, which differ because they were build based on the biographic situation of their members, their histories experienced as a group. This system, for each group, is considered an unquestionable code. According to this code, the type of behavior of the individuals from another social group is not acceptable, because it does not agree with that considered correct, it does not have the validity accepted by the group; thus, the behavior of the group that seeks acceptance is considered inadequate. Therefore, nurses who were once nursing auxiliaries/technicians will have to review and re-elaborate their relevance system so it is possible to interpret the changes that are wanted from them.

The conventional-education nurses in the category Professional development show that they try to encourage and make sure that nurses who had been nursing student-workers participate in development courses to guarantee their technical preparation to perform their nurse role well, and, thus, be told apart from nursing auxiliaries/technicians.

The context of meanings, that is, the "motives why" of conventional-education nurses in their relationship with nurses who had been nursing student-workers, shows the difficulty that the former face when as a leader. They are unable to redirect the relationship with nursing auxiliaries/technicians, and are discouraged regarding their professional development, associating these difficulties to the biographical situation experienced in their condition as a nursing student-worker.

Both lived types of nurses report readapting as primary to transformation. For it to occur, the nurse that was once a nursing student-worker needs to feel a real member of the new group and try to act as expected for a nurse. However, as we observed, this does not occur, because they experience difficulties. Their reference code does not correspond to that of the other lived type and vice-versa. They still do not make out the same view of the world around them, and, therefore, despite both agreeing about what should be done, they disagree about the way it is done.

The attitude of the nurses who had been nursing students-workers toward the nursing auxiliaries/ technicians are described as protectionist; they lack leadership over the team, and, in fact, allow being "disrespected" by their subalterns. This submissive behavior toward the subalterns is not recognized as belonging to the appropriate nurse behavior code; therefore, it is considered inappropriate.

In the category discouragement, they reported that the nurses who had been nursing student-workers did not attend conventions or courses, and did not show interest in their own professional development. However, the category professional development is stressed as one of the "motives to" needed for making the transformation possible, since it would allow for a new view to occur, in addition to a change in behaviors, appreciation, and dynamics.

The conventional-education nurses describe the biographical situation of those who had been nursing students-workers from different aspects. In this category, the conventional-education nurses recover from the past of nurses who had been nursing student-workers the justifications for the present situation. The financial problems they dealt with during the undergraduate course years are stated as the cause for the little involvement in attending courses, conventions, and purchasing reading material to keep up to date and improve professionally.

These financial difficulties would also be in the genesis of the fear that became evident : “... they are afraid of losing their job, afraid of getting 'told off', afraid of not being a good professional, afraid of everything that comes up..."

Losing the job can mean worsening a difficult financial situation that, as stated before, is part of the lives of this lived type. Other fears are added, since they know they are the center of attention of both nurses and nursing auxiliaries/technicians.

What determines a person's biographical situation is the physical and sociocultural environment they live $i^{(4)}$. In that environment, a person assumes a status, their moral and ideological stance. Knowing one's biographical situation allows for, from his/her past, understanding and justifying their present and future actions.

The lived type "conventional-education nurse in the face-to-face relationship with nurses who had been nursing students-workers" was that which expects nurses to develop a leadership position toward the nursing team and speak up; they also want them to improve professionally to achieve good professional performance and differ from nursing auxiliaries/ technicians, since the context of meanings shows that they are unable to redirect the relationship with these nursing auxiliaries/technicians, which is a necessary condition to make them leaders; they are discouraged toward professional improvement, and their current life condition is a consequence of their biographical situation.

\section{CONCLUSIONS}

We noticed that being a nurse after having been a nursing student-worker in a world with other nurses means experiencing a transformation not only in their 
everyday routine, but also transforming their inner environment, their behavior and social relationship.

For this to occur, they need, according to the adopted framework, decode a guiding code that is expected from the nurse; however, they realized that not even sharing the same environment with the nurses' social group nor the undergraduate course were sufficient to make them decipher the unknown code, because the reference code regarding the expected nurse social behavior was constructed by conventional-education nurses throughout the history of nursing, heirs of the "ladies-nurses", a social group with a biographical situation markedly different from that of nursing auxiliaries/technicians.

On the other hand, the heirs to the "nurses", the nursing auxiliary/technician social group also has its own reference code, constructed over their biographical situation.

The life world of the two social groups is quite different. Therefore, each group uses their own relevance systems and codes as a guide that the group considers safe for their interpersonal relationships.

Thus, the process of nursing auxiliaries / technicians do not instantly "undress" from their experience to absorb another culture, considering that some beliefs and values are not yet understandable to them. They are expected to have some skills that are very specific and necessary to develop the process of managing

\section{REFERENCES}

1. Costa MLAS. Estudante-trabalhador de enfermagem: desvelando esta nova realidade [tese]. São Paulo: Escola de Enfermagem da Universidade de São Paulo; 1992.

2. Costa MLAS. Ser enfermeiro tendo sido estudantetrabalhador de enfermagem: um enfoque da fenomenologia social [tese]. São Paulo: Escola de Enfermagem da Universidade de São Paulo; 2001.

3. Schutz A. Fenomenologia del mundo social: introducción a la sociología comprensiva. Buenos Aires: Paidós; 1972.

4. Schutz A, Wagner HR, organizador. Fenomenologia e relações sociais: textos escolhidos de Alfred Schutz. Rio de Janeiro: Zahar; 1979.

5. Jesus MCP. A educação sexual na vida cotidiana de pais e adolescentes: uma abordagem compreensiva da ação social [tese]. São Paulo: Escola de Enfermagem da Universidade de São Paulo; 1998.

6. Capalbo C. Metodologia das ciências sociais: a health care work.

Besides, there is also the fact that nursing schools are still unprepared to discuss the issue of professional mobility and the consequences involved, despite the of the education organizations is to promote a change in the behavior of nursing workers who are studying to become nurses. This study showed that there is a need to cast a "close look" toward this particular student. This concern should not focus exclusively on the technical-scientific issues, or actions, rather it should also address these subjects' attitudes. We believe this task is a great challenge because it involves the commitment to these individuals' social transformation.

We must face the challenge of taking this discussion not only to nursing schools, but also to every location that involves nursing, since we believe that continuous education could take, together with schools, the responsibility to revert this situation, particularly among nurses who had been nursing student-workers and are already in the work market. The great challenge of change is not cast only toward schools and continuing education services of health institutions, but also toward the subjects that experienced this situation.

We hope that the category interpretations and the considerations presented in this study serve as an opportunity so each of use, nursing professionals, can reflect about our responsibility in this situation.

fenomenologia de Alfred Schutz. 2a ed. Londrina: Universidade Estadual de Londrina; 1998.

7. Brasil. Ministério da Saúde. Conselho Nacional de Saúde. Comissão Nacional de Ética em Pesquisa. Resolução 196/ 96. Dispõe sobre pesquisa envolvendo seres humanos. Brasília: Ministério da Saúde; 1996.

8. Martins J, Bicudo MAV. Estudos sobre existencialismo, fenomenologia e educação. São Paulo: Moraes; 1983.

9. Merighi MAB. Trajetória profissional das enfermeiras obstétricas egressas_da Escola de Enfermagem da Universidade de São Paulo: um enfoque da fenomenologia social. Rev Latinoam Enferm. 2002; 10(5): 644-53.

10. Fustinoni SM. As necessidades da parturiente: uma perspectiva compreensiva da ação social [tese]. São Paulo: Escola de Enfermagem da Universidade de São Paulo; 2000.

11. Schutz A. Estudios sobre teoría social. Buenos Aires: Amorrortu; 1974. 